e-ISSN: 2289-7127

(C) RMP Publications, 2019

DOI: $10.26666 /$ rmp.jesr.2019.5.1

\title{
Development of High Speed Train Door System for Improving Maintenance
}

\author{
Kye-Seung Lee and Cha-Jung Yun \\ Korea Railroad Corporation \\ 240, Jungang-ro, Dong-gu, Daejeon, Republic of Korea
}

\begin{abstract}
The train door of the high speed train currently operation in Korea is consist of 46 train set(1,656 units) and they are all made up of imports. The problem is that it is difficult to service parts at the right time for breakdown or replacement as parts are imported. Moreover, it is difficult to secure service parts when they are discontinued due to characteristics of imported parts, this leads to an increase in overall maintenance cost. As a result, the Korea Railroad Corporation has developed localization of the high speed train door system and currently progress the on-track test to verify reliability. In this paper, the design and production process of development product and result of performance test are summarized. In addition, the technical improvement of the developed product compared to the existing product was confirmed and the method for securing the reliability was considerate.
\end{abstract}

Key words: High speed train, Localization, On-track test, Reliability test, Failure rate analysis

\section{INTRODUCTION}

The high-speed trains currently operating in Korea are introduced and operated in 2004 through the consortium of Alstom's original technology and Korean railway rolling stock manufacturers and parts manufacturers. Therefore, since the technology was transferred from Alstom, all of the key vehicle parts are made up of imported parts and repair parts used for car maintenance depend on imports. The problem is that the price of repair parts have risen due to the discontinuation of introduction vehicle, expensive maintenance parts have to be imported and used for maintenance of high-speed trains. Moreover, maintenance problems are occurring because it is difficult to obtain repair parts that are suitable for the time of repair.

To solve this problem, Korea Railroad Corporation developed localization for major parts of high-speed train, Among them the high speed train door system was designed to enable one-to-one compatibility with existing products. In particular, various technological improvements were carried out, such as improving the resistance and maintainability of parts and preventing weld deformation through the manufacture of dedicated jig. In this paper, the technical improvement of research and development products and differentiation from existing products were presented, and performance verification plans including durability target design were established to secure reliability. Based on the established plans, component performance and durability tests were conducted and the results summarized.

\section{MAIN SUBJECT}

Composition and characteristics of development product The door system consists of five components, door panel, looking device, step of door, stabilizer, emergency opening device and these are consist of 261 items in total. For localization development of each component, 3D and X-Ray images were taken of existing products and prototypes were produced based on this. Fig 1 shows the schematic of the development product.

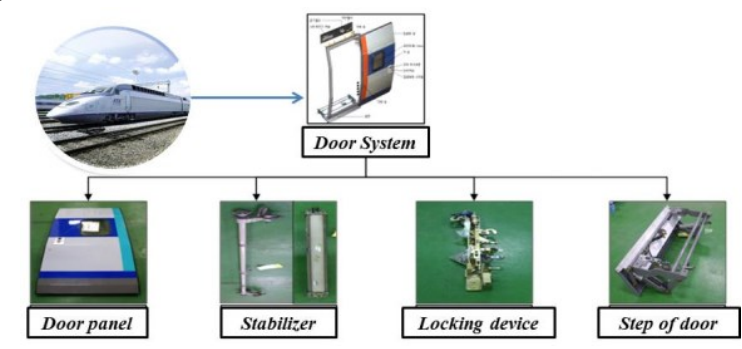

Fig 1 Schematic of the development product

Corresponding Author: Kye-Seung Lee, Korea Railroad Corporation, krinke49@gmail.com, +821088932631 
The door panel was manufactured by changing the existing mold and method of construction because the cross section of the panel frame was complicated and the shape didn't come out properly when bending. In addition, in order to solve the joint problem of the existing separation type sealing seals, the sealing seals have been improved in integral form to improve workability. Fig 2 shows the parts of door panel.

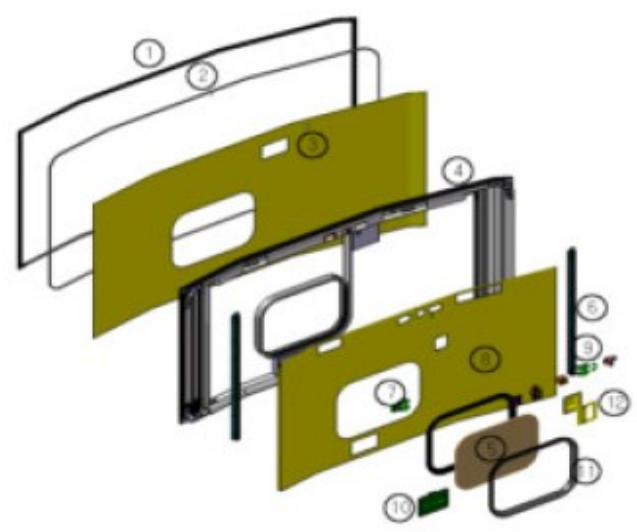

Fig 2 Parts schematic of door panel

Step of door is improved to be able to operate even at extremely low temperature by improving the cold resistance of the driving cylinder to compensate for the problem that the operation cannot be performed due to freezing during cold weather. Also, the step mounting jig was manufactured in order to prevent the occurrence of interference when mounting on the vehicle body due to the deformation of the welding. Fig 3 shows the parts of step.

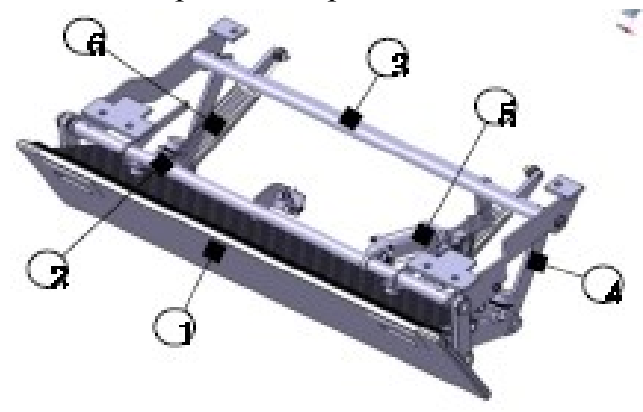

Fig 3 Parts schematic of door step

Stabilizer and locking device also improve performance at extremely low temperature through improved cold resistance. And the grease inlet was changed to improve the convenience during maintenance, which shortened the maintenance time and increased the operator's convenience. In particular, the stabilizer expanded the operating temperature range by changing the seal structure of the pneumatic motor. Fig 4 shows the parts of stabilizer and locking device.
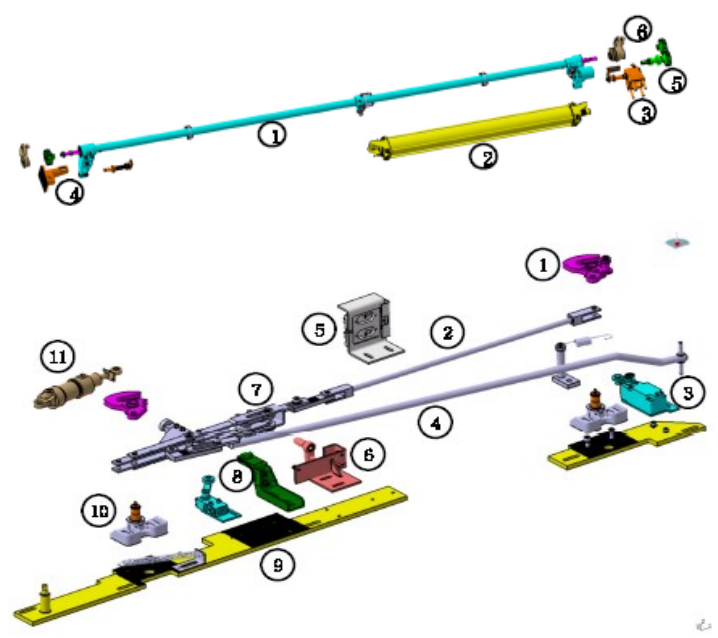

Fig 4 Parts schematic of stabilizer(top) and locking device(bottom)

Establishment of performance verification test plan In order to apply the developed product to actual rolling stock, a certain level of reliability must be secured. For this one, the technology trend and relevant laws or specification of door system were investigated and test plan to verify the performance of developed products was established considering various problems such as compatibility with existing door system, airtightness, environmental resistance, secure of customer safety, etc.

\section{High speed train door system technology trend}

The door system currently used in high-speed rail cars in Korea is the source technology of France's Faiveley and Germany's Bode. The problem is that there is only a technical alliance with domestic parts manufacturers, but there is no actual production. The type and characteristics of door system technology can be classified according to the shape and driving method, and their advantages and disadvantages are shown in Table 1.

Table 1 Pros and cons according to door structure

\begin{tabular}{|c|l|c|}
\hline \multicolumn{2}{|c|}{ Door shape } & \multicolumn{2}{|c|}{ Pros and cons } \\
\hline \multirow{2}{*}{ Pocket Sliding } & Pros & $\begin{array}{c}\text { Simple operation movement } \\
\text { for easy inspection, } \\
\text { High reliability }\end{array}$ \\
\cline { 3 - 4 } & Cons & Vulnerable to confidentiality \\
\hline & Pros & $\begin{array}{c}\text { Simple operation movement } \\
\text { for easy inspection, } \\
\text { High reliability }\end{array}$ \\
\cline { 2 - 4 } & Cons & $\begin{array}{c}\text { Vulnerable to confidentiality, } \\
\text { Vulnerable to external dust }\end{array}$ \\
\hline & Pros & $\begin{array}{c}\text { Excellent confidentiality, } \\
\text { Low driving resistance }\end{array}$ \\
\cline { 2 - 3 } & Cons & $\begin{array}{c}\text { Difficult to inspection } \\
\text { due to complicated } \\
\text { operation movement, }\end{array}$ \\
\hline
\end{tabular}




\begin{tabular}{|c|c|c|}
\hline & & Low reliability \\
\hline Pros & $\begin{array}{c}\text { Excellent confidentiality, } \\
\text { Low driving resistance }\end{array}$ \\
\cline { 2 - 3 } & Cons & $\begin{array}{c}\text { Difficult to inspection } \\
\text { due to complicated } \\
\text { operation movement, } \\
\text { Low reliability }\end{array}$ \\
\hline
\end{tabular}

Investigate domestic/international standards and operator requirements

Domestic standards related to the door system are "KS R 9247 : Electric door system used on electric rail carTest methods", "KRS CB 0001-10(R) : Entrance door for electric rail car", but all of them are suitable for electric rail car. So it is necessary to amend or enact it as a standard suitable for use in high speed trains. International standards include "EN14752: Railway Application-Body side Entrance Systems", and the main contents are as follows [1].

\section{Mechanical strength}

* Mechanical strength of door

- Basic strength: Clause 4.12.3 of EN50125-1

- In case of overturned: EN12663

- Vibration and impact resistance: EN12663, 61373

* Mechanical strength of door step

- There should be no permanent deformation by applying a concentrated load of $2 \mathrm{kN}$ vertical load and a distributed load $(4 \mathrm{kN} / \mathrm{m})$ in the center of the total length of the step

Obstacle detection of door step

- The maximum spreading force of the outer sliding step should not exceed $300 \mathrm{~N}$

- Requirements for folding door step or any form door step are defined in the contract

\section{Emergency operation}

- Escape device must be valid even if emergency escape power is cut off by making emergency exit handle on the door

- The action force of emergency escape handle does not exceed $100 \mathrm{~N}$

- Do not operate emergency escape at speeds above $10 \mathrm{~km} / \mathrm{h}$

Based on the main points of the above standard, the requirements of high speed train operation and maintenance managers were collected in order to grasp the practical considerations in performance verification.

Compatibility and ease of maintenance
- Installation compatibility with existing high speed train door

- Need to secure of communication interface stabilization

- Improving the position of the grease inlet

Environmental resistance and durability

- Need to prevent freezing of door step in winter

- Need to secure mechanical durability

Secure safety and confidentiality

- Developed to prevent door system from opening when a certain seed is exceeded

- Review the application of expansion seal rubber to secure airtightness

Performance verification plan for development product In order to derive an objective performance verification method, performance verification methods were sought by analyzing domestic and international standards, regulations, and operator requirements. The details of the verification measures are shown in Table 2.

Table 2 Test item and criteria

\begin{tabular}{|c|c|c|c|}
\hline Test type & Test item & Test standard & $\begin{array}{c}\text { Confirm } \\
\text { institution }\end{array}$ \\
\hline \multirow{7}{*}{$\begin{array}{l}\text { Component } \\
\text { performance } \\
\text { test }\end{array}$} & Performance test & $\begin{array}{c}\text { Examination } \\
\text { procedure }\end{array}$ & \multirow{6}{*}{$\begin{array}{c}\text { Qualified } \\
\text { office } \\
\text { (Korea } \\
\text { Institute } \\
\text { Machinery } \\
\& \\
\text { Materials) }\end{array}$} \\
\hline & $\begin{array}{c}\text { Waterproof \& } \\
\text { Confidential test }\end{array}$ & IEC 14752 & \\
\hline & $\begin{array}{c}\text { High temperature } \\
\text { test }\end{array}$ & IEC 60068-2-2 & \\
\hline & $\begin{array}{c}\text { High temperature \& } \\
\text { High humidity test }\end{array}$ & $\begin{array}{c}\text { IEC 60068-2- } \\
30\end{array}$ & \\
\hline & $\begin{array}{c}\text { Low temperature } \\
\text { test }\end{array}$ & IEC 30068-2-1 & \\
\hline & $\begin{array}{c}\text { Vibration \& Shock } \\
\text { test } \\
\end{array}$ & IEC 613731 & \\
\hline & Durability test & $\begin{array}{l}\text { Examination } \\
\text { procedure }\end{array}$ & $\begin{array}{l}\text { Verification } \\
\text { office } \\
\text { (Rolling } \\
\text { stock ENG) }\end{array}$ \\
\hline \multirow{3}{*}{$\begin{array}{l}\text { On-track } \\
\text { test }\end{array}$} & Static test & $\begin{array}{c}\text { FGI } \\
\text { procedure }\end{array}$ & \multirow{3}{*}{$\begin{array}{c}\text { Operation } \\
\text { institution } \\
\text { (Korea } \\
\text { railroad } \\
\text { corporation) }\end{array}$} \\
\hline & Dynamic test & Dynamic \& & \\
\hline & $\begin{array}{l}\text { Four seasons } \\
\text { On-track test }\end{array}$ & $\begin{array}{l}\text { Four seasons } \\
\text { test procedure }\end{array}$ & \\
\hline
\end{tabular}

\section{Calculation target value of the durability test}

The purpose of the durability test during the performance test is to ensure the reliability of the system. Reliability is the possibility that a product or system can perform its required function in a given period and condition.

Reliability test include performance test, environmental test, and life test, etc. Durability test is a type of life test. Life test is an important test for products requiring measurement of abrasion or service life such as 
electric/electronic parts and machinery parts. However, due to the test takes too long, a zero-failure test method is mainly used. A zero-failure test means that if there is no failure, the product is judged to meet the reliability requirements [2][3]. In this section, the zero-failure test time was calculated by deriving the warranty life (Minimum period of time to perform the required function without failure) of the developed product according to the formula (1).

$$
\begin{gathered}
\boldsymbol{t}_{\mathbf{z f t t}}=\boldsymbol{B}_{\mathbf{1 0 0} \boldsymbol{p}} \cdot\left[\frac{\ln (\mathbf{1}-\boldsymbol{C L})}{\boldsymbol{n} \cdot \ln (1-\boldsymbol{p})}\right]^{\frac{1}{\beta}} \\
\boldsymbol{B}_{\mathbf{1 0 0} p}: \text { Warranty life } \quad \mathrm{CL}: \text { Confidence Level } \\
\mathrm{n}: \text { number of sample } \quad \beta: \text { Weibull shape parameter }
\end{gathered}
$$

In order to calculate the number of operation for the calculation warranty life, one month's driving records and timetables of high-speed train doors were investigated and analyzed. Table 3 shows the average number of door operated and the number of door operated at once during each day.

Table 3 Average number of door operation

\begin{tabular}{|c|c|c|c|c|}
\hline Day & $\begin{array}{c}\text { Mon - } \\
\text { Tue }\end{array}$ & $\begin{array}{c}\text { Wed }- \\
\text { Thu }\end{array}$ & $\begin{array}{c}\text { Fri - } \\
\text { Sun }\end{array}$ & Average \\
\hline $\begin{array}{c}\text { Average } \\
\text { operating time }\end{array}$ & 7.4 & 7.4 & 7.3 & 7.4 \\
\hline
\end{tabular}

In addition, a survey of high-speed train operation for a month showed that the average one-way operation was five times a day. Based on this, the number of door opening and closing times per day was calculated as shown in Equation (2) by considering the number of irregular door opening and closing by the train crew and the number of door opening and closing by inspection.

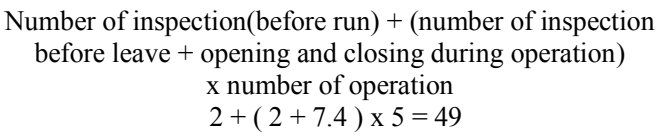

The final warranty life was calculated as shown in Equation (3) by setting 16 months as the warranty life period based on the high-speed train full general inspection based on the number of opening and closing times calculated above [4].

Door opening and closing by 1 day x 1 year x 16 months $49 \times 365 \times 1.33$ (year) $=23787.05$

The door system has a warranty life time of 23,787 opening and closing cycles for 16 months. The confidence level(CL) requires a high level of confidence, as it is a major device that greatly affects passenger safety and train operation in the event of a breakdown door system failure. Therefore, the confidence level was $95 \%$ and B1 life was applied. The life distribution follows the Weibull distribution, main failure mode is a leakage caused by deterioration of the pneumatic motor piston seal. Through this, the shape parameter was applied to 2.0. The number of samples was determined to be one due to research of period and space constraints.

Based on the above conditions, the zero-failure test time was derived from equation (1), it was calculated 410,678 times. thus, establish a durability test target value of approximately 411,000 times.

Table 4 No-fault test time

\begin{tabular}{|c|c|}
\hline Item & Set point \\
\hline Warranty life & 23,787 cycle \\
\hline $\begin{array}{c}\text { Confidence Level } \\
\text { (CL) }\end{array}$ & $95 \%$ \\
\hline Number of sample & 1 \\
\hline Distrust percent(p) & 0.01 \\
\hline Shape parameter & 2.0 \\
\hline & $t_{z f t t}=23,787 \cdot\left[\frac{\ln (1-0.95)}{1 \cdot \ln (1-0.01)}\right]^{\frac{1}{2}}$ \\
No-fault test time & $=410,678$ Cycle \\
\hline
\end{tabular}

\section{Durability performance and on-track Test}

Based on the test items in Table 2 and the durability target values calculated in Section 2.2.4, component performance, durability and on-track tests were conducted. In case of component test, it is mainly done in the indoor environment and there is no big deficiency in safety. but on-track tests need to be reviewed for safety because tests are conducted externally and risk factors exist. Therefore, risk analysis was conducted according to the railroad safety management regulations for on-track test progress. And based on the results, safety management and progress procedures confirmed during the test through safety evaluation.

Risk factors that can occur during the test are 5 items in total. The criticality and occurrence frequency of each factor is summarized in Table 5.

Table 5 Frequency of occurrence, criticality by risk factor

\begin{tabular}{|l|c|c|c|}
\hline \multicolumn{1}{|c|}{ Risk factor } & Frequency & Criticality & Severity \\
\hline Locking hinge failure & F3 & C3 & B \\
\hline Door operation control failure & F5 & C2 & B \\
\hline $\begin{array}{l}\text { Door and propulsion device } \\
\text { burn-out }\end{array}$ & F2 & C4 & B \\
\hline Door engine failure & F2 & C2 & B \\
\hline Air leakage & F3 & C2 & B \\
\hline
\end{tabular}

Risk factors were selected by combining frequency ratings $(\mathrm{F})$ and criticality $(\mathrm{C})$ for each factor. The frequency is closer to F10, the lower incidence rate and the criticality is closer to $\mathrm{C} 1$, the higher severity. Based on the results of the analysis, procedures for coping 
with failures and test procedures were prepared, as shown in Figure 5.

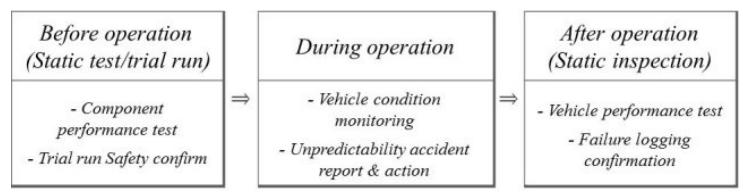

Fig 5 Safety management measures for on-track test

The inspection was conducted focusing on the frequency and severity of accident to ensure effective accident prevention. During operation, rolling stock condition monitoring was used to prepare handling procedures and measure plans for failures. After the operation, static inspection was conducted and the test driving checklist was prepared in accordance with the standard test operation of rolling stock.

\section{Component Performance Test}

The component test was conducted on the main parts, and the durability test was performed on the door system including door step and four type components, such as an electromagnetic valve, a pneumatic motor, a door step cylinder, and a locking cylinder. Each test was conducted according to the test criteria of Table 2 through an accredited testing institution, and the evaluation results were collected with satisfaction or dissatisfaction.

Fig. 6 shows the vibration shock test of the door step cylinder among the many tests. When acceleration shocks of front and rear $0.70 \mathrm{~m} / \mathrm{s}^{\wedge} 2$, left and right $0.45 \mathrm{~m} / \mathrm{s} \wedge 2$, and up and down $100 \mathrm{~m} / \mathrm{s} \wedge 2$ are applied to the frequencies 5,20 , and $150 \mathrm{~Hz}$, there should be no appearance damage such as rupture or cracking. Two samples were evaluated and all of them satisfied the evaluation criteria by confirming that there was no appearance damage. It was confirmed that all other test results satisfied the evaluation criteria.

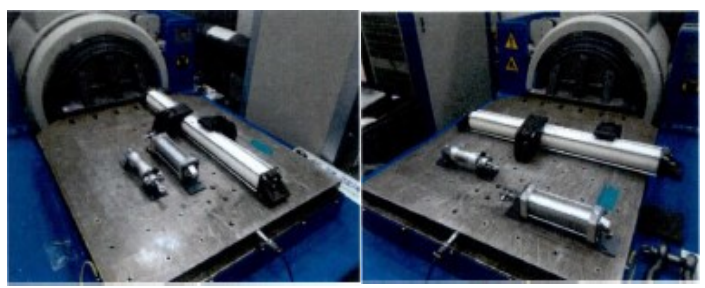

Fig 6 Vibration test of door step cylinder

Durability tests also confirmed that the door system was operating without problems during the 411,000 target test times. In fact, although the number of tests is defined as 300,000 times in domestic standards, more reliability is achieved by applying more than 110,000 test times.

\section{On-track test of developed product}

The static and dynamic test items, test methods, and evaluation criteria of the developed products were referred to "KS R 9247 : Electric door system used on electric rail car-Test methods" and "Full general inspection exclusive test procedures of high speed train door system, and the test result was determined to be good or bad. The items of each test were constructed as Tables 6 and 7 [5].

Table 6 Item of dynamic test

\begin{tabular}{|c|c|c|c|}
\hline No. & \multicolumn{2}{|c|}{ Test type } & Test item \\
\hline 1 & \multirow{6}{*}{\multicolumn{2}{|c|}{$\begin{array}{l}\text { Door system } \\
\text { Individual test }\end{array}$}} & Closing test \\
\hline 2 & & & $15 \mathrm{~km}$ speed test \\
\hline 3 & & & $\begin{array}{l}\text { Emergency opening } \\
\text { test }\end{array}$ \\
\hline 4 & & & $5 \mathrm{~km}$ speed test \\
\hline 5 & & & Obstacle detection test \\
\hline 6 & & & Fault display test \\
\hline 7 & \multirow{4}{*}{$\begin{array}{c}\text { Door } \\
\text { Examination } \\
\text { test }\end{array}$} & \multirow{3}{*}{$\begin{array}{c}\mathrm{P} 1 / \mathrm{P} 2 \\
\text { Cab control }\end{array}$} & Operation test \\
\hline 8 & & & $\begin{array}{l}\text { External individual } \\
\text { opening test }\end{array}$ \\
\hline 9 & & & $\begin{array}{l}\text { Washing chamber } \\
\text { input and release }\end{array}$ \\
\hline 10 & & $\begin{array}{l}\text { 'C' car } \\
\text { control }\end{array}$ & Operation test \\
\hline
\end{tabular}

Table 7 Item of static test

\begin{tabular}{|c|c|c|}
\hline No. & Test type & Test item \\
\hline 1 & \multirow{9}{*}{$\begin{array}{c}\text { Door } \\
\text { system } \\
\text { individual } \\
\text { test }\end{array}$} & $5 \mathrm{~km}$ speed test \\
\hline 2 & & $15 \mathrm{~km}$ speed test \\
\hline 3 & & Fault display test \\
\hline 4 & & Emergency opening test \\
\hline 5 & & Door opening test during operation \\
\hline 6 & & Individual door opening test \\
\hline 7 & & Door opening and closing test in cab \\
\hline 8 & & $\begin{array}{c}\text { Door opening and closing test in } \\
\text { passenger car }\end{array}$ \\
\hline 9 & & Automatic cleaning program test \\
\hline
\end{tabular}

Among the test items, the speed test evaluated the test results by measuring the operation time and in the case of the failure manifestation test evaluated results by confirming the Fail Display Trailer and the switchboard. Other tests confirmed the buzzer sound, lamp lighting according to the switch handling and mechanical operation state. In order to increase the reliability of the test results, the on-track test was conducted in cooperation with the Korea railroad corporation's metropolitan rolling tock maintenance group, a domestic high-speed train maintenance organization. The test was conducted in the presence of the door system manufacturer and the certificate authority, and Figure 7 shows the obstacle detection and emergency opening test as part of the performance test. 

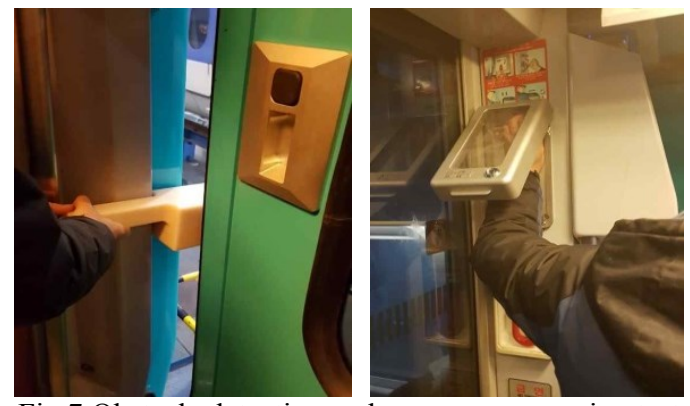

Fig 7 Obstacle detection and emergency opening test

Obstacle detection test was performed by inserting a $10 \mathrm{~cm}$ chock or jig when the door was closed and then reopening after detecting the obstacle and displaying failure in the Fail Display Trailer. In the case of the emergency opening test, the door opening time was measured during the emergency valve operation and judged by the appearance damage of the parts between opening and closing. The test results were satisfied with the evaluation criteria and all other test items were confirmed to meet the evaluation criteria.

In accordance with the passing of the above test, the development product is installed in the operating rolling stock and the four-seasons(14months) on-track test is being proceeded. As this is an important part that directly affects vehicle performance and safety, it was carried out to secure reliability depending on the Korea railroad operator's regulations in consideration of Korea's climate environment conditions. Fig 8 shows the replacement of parts about development product, which is currently under test about $80 \%$ without any problems.
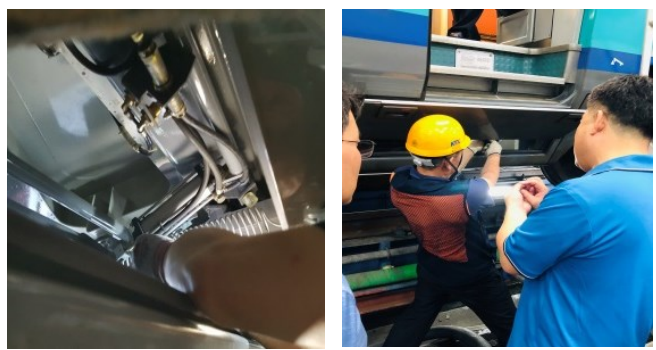

Fig 8 Door step value and related parts replacement

\section{CONCLUSION}

The biggest technical difference of the development product compared to the existing product is improvement of cold resistance by improving the performance of cylinder and electromagnetic valve and improvement of maintainability by reflecting the opinion of the maintainer (eg, changing the position of the grease inlet). Table 8 shows the degree of improvement in cold resistance compared to existing products of major components.
Table 8 Main component operating temperature

\begin{tabular}{|c|c|c|}
\hline Component & Existing product & Development product \\
\hline $\begin{array}{c}\text { Electromagnetic } \\
\text { valve }\end{array}$ & $-25^{\circ} \mathrm{C} \sim 70^{\circ} \mathrm{C}$ & $-40^{\circ} \mathrm{C} \sim 70^{\circ} \mathrm{C}$ \\
\hline $\begin{array}{c}\text { Pneumatic } \\
\text { motor }\end{array}$ & $-25^{\circ} \mathrm{C} \sim 70^{\circ} \mathrm{C}$ & $-30^{\circ} \mathrm{C} \sim 80^{\circ} \mathrm{C}$ \\
\hline Step cylinder & $-25^{\circ} \mathrm{C} \sim 70^{\circ} \mathrm{C}$ & $-30^{\circ} \mathrm{C} \sim 80^{\circ} \mathrm{C}$ \\
\hline $\begin{array}{c}\text { Locking } \\
\text { cylinder }\end{array}$ & $-25^{\circ} \mathrm{C} \sim 70^{\circ} \mathrm{C}$ & $-30^{\circ} \mathrm{C} \sim 80^{\circ} \mathrm{C}$ \\
\hline
\end{tabular}

The biggest effect of localization is the reduction of parts replacement costs due to import substitution. The price of imported door system is $\$ 410,000$, while the cost of development is $\$ 210,000$, which can be reduced by about $50 \%$. In addition, considering the component life cycle of high-speed trains (12 years), the import substitution effect of localization development can save about $\$ 7.2$ million per train. In addition, technical improvements were achieved, such as securing the design ability and manufacturing technology for the high speed train door system, avoiding technology dependency with foreign companies, possessing door control technology and fault detection technology, and preventing safety accidents during operation.

\section{REFERENCES}

[1] J.H Lee, Y.J Kim and C.J Yoon, 2012. Study on method of passenger door in the rolling stock performance evaluation, The Korean Society For Railway, 1653-1658.

[2] M.S Chang, B.O Choi and C.J Yoon, 2014. Reliability Allocation of KTX Door System Using BlockSim, The Korean Society of Mechanical Engineers, 2225-2228.

[3] B.O Choi, B.S Kang and J.H Lee, 2013. Development of reliability test of high-speed train door system, Korean Institute Of Industrial Engineers, 2501-2505.

[4] J.H Lee, C.J Yoon and M.S Chang, 2014. Zero Failure Test Time Calculation for Durability Test of KTX Door System, The Korean Society For Railway, 529-534.

[5] W.D Lee, S.K Park, K.K Lee and J.H Lee, 2014. Analytical Study to Check Safety of Folding-type Staircase in High Speed Rolling Stock, The Korean Society For Railway, 87-93. 